\title{
The profile of students' metacognition in solving analytic geometry: Gender and cognitive style perspective
}

\author{
Muhammad Ridlo Yuwono ${ }^{1}$, Septiana Wijayanti ${ }^{2}$
}

\begin{abstract}
Abstrak: Peneltian studi kasus ini bertujuan untuk mendiskripsikan metakognisi mahasiswa lakilaki dalam memecahkan masalah geometri analitik ditinjau dari gaya kognitif. Subjek penelitian adalah mahasiswa matematika yang mengambil mata kuliah Geometri Analitik dipilih dengan teknik purposive sampling. Instrumen penelitian meliputi instrumen utama (peneliti) dan instrumen bantu (soal pemecahan masalah geometri analitik). Data dikumpulkan dengan menggunakan metode think aloud. Analisis data dilakukan dengan cara reduksi data, penyajian data, dan penarikan kesimpulan. Hasil penelitian menunjukkan pada tahap memahami masalah, mahasiswa laki-laki FI dan FD membaca soal dalam hati serta tidak menuliskan yang diketahui dan ditanyakan. Pada tahap menyusun rencana, mahasiswa laki-laki FD menggambar unsur-unsur yang diketahui secara lengkap, sedangkan mahasiswa laki-laki FI tidak melakukannya. Pada tahap melaksanakan rencana, mahasiswa laki-laki FI menyadari terdapat strategi yang kurang efektif, sedangkan mahasiswa lakilaki FD tidak melakukannya. Pada tahap mengecek kembali, mahasiswa laki-laki FI menggunakan strategi bervariasi dan mengecek apakah hasil yang diperoleh memenuhi kriteria yang digunakan untuk memecahkan masalah, sedangkan mahasiswa laki-laki FD menggunakan strategi yang bervariasi tetapi dibantu dengan pertanyaan. Penelitian ini menunjukkan bahwa mahasiswa laki-laki FI dan FD memiliki profil metakognisi yang sama pada tahap memahami masalah namun berbeda pada menyusun rencana, melaksanakan rencana dan mengecek kembali hasil pemecahan masalah.
\end{abstract}

Kata kunci: Metakognisi, Gender, Geometri analitik, Gaya kognitif, Pemecahan masalah

Abstract: This case study aimed to describe the metacognition of male students in solving analytical geometry problems referring to cognitive style. The subjects were mathematics students who enrolled in Analytic Geometry course and selected by purposive sampling technique. The instrument of this research was the researcher as the main instrument and a problem-solving test as the supporting instrument. Data were collected using a think-aloud method and analyzed through three steps: reducing data, presenting data, and drawing conclusions. The results of this study show that at the stage of understanding the problem, FI and FD male students read questions silently and did not write what is known and asked in the problem. At the planning stage, FD male student drew elements that are fully known, while male FI students did not do so. At the stage of implementing the plan, FI male student was aware of less effective strategy, while FD male students did not. In re-checking phase, FI male student used a variety of strategies and checked whether or not the results meet the criteria of solving the problem, while FD male students used a variety of strategies but are assisted with a prompt. This study shows that FI and FD male students have similar metacognition profile at the stage of understanding the problem, but they are different in planning, doing the plan and re-checking the result of problem-solving.

Keywords: Metacognition, Gender, Analytic geometry, Cognitive style, Problem-solving

\footnotetext{
${ }^{1}$ Universitas Widya Dharma, Jl. Ki Hajar Dewantara Klaten Utara, Klaten, Indonesia, ridloyuwono@unwidha.ac.id

${ }^{2}$ Universitas Widya Dharma, Jl. Ki Hajar Dewantara Klaten Utara, Klaten, Indonesia
} 


\section{A. Introduction}

The activity of solving the problem is as a basic activity for humans (Hudojo, 2003). Most of human life is faced with problems. A question is a problem if someone does not have rules that can be immediately used to answer the question (Hudojo, 2003). It appears that problemsolving is high mental activity. A question is considered a problem depending on the individual. Ulya (2015) found that there is a significant positive relationship between cognitive style and students' problem-solving abilities. Cognitive style is an individual's perception in processing information obtained from the environment (Mammarella, Borella, \& Fairfield, 2014). Cognitive style dimensions are divided into two fields, field dependent (FD) and field independent (FI).

The students with FD and FI have different thinking in solving mathematical problems. Ngilawajan (2013) confirmed that FI students understand the problems of derivative better than FD students. The research of Kafiar, Kho and Triwiyono (2015) showed that in solving problems according to plan and checking the results, FI subjects are better than FD subjects. Also, the FI subjects show a good understanding of the concept of the system of three variable linear equations when compared to the FD subjects. It can be said that FI individuals have a better understanding of concepts than FD individuals. There is a positive relationship between cognitive style and student learning outcomes in geometry courses (Udiyono \& Yuwono, 2018). It means students who have FI cognitive style have better geometry achievement than those of FD's.

There are differences in the thinking processes of male and female students in solving problems. Aini (2017) found that FI female students have a better thinking process than FI male students in solving problems. In understanding the problem, FI male students need a longer time than FI female students to understand the problem. In the planning stage, FI female students can plan the solution appropriately, while FI male students make mistakes in making illustrations. At the re-checking stage, FI female students are more confident and more confident with the completion that has been done than FI male students.

In solving analytical geometry problems online and circle materials, the students make conceptual errors, miscalculation, strategic errors and systematic errors (Imswatama \& Muhassanah, 2016). Students find it difficult to remember the analytic geometry formulas and arrange the steps used in solving the problem of analytic geometry (Subita \& Kholid, 2017). It shows that students still have difficulties in solving the problem of analytic geometry.

Metacognition has an essential role for students in solving the problem (Anggo, 2011). Metacognition means meaningful cognition (Papleontiou-louca, 2003). It refers to second-order cognition, which is thinking about the mind, knowledge of knowledge or reflection on action. There are two essential things from the understanding of metacognition, namely (1) awareness of cognition, and (2) control or regulation of cognition processes when learning or solving mathematical problems and ensuring that cognitive goals have been achieved (Chairani, 2016). Metacognition ability has a positive relationship with students' cognitive style (Munandar, 2010).

Male and female high school students have been able to carry out the metacognition process in solving geometry problems (Suhandono, 2017). Male and female students with the same cognitive style have different metacognition processes. However, male students with FI and FD cognitive styles do not have a different process of metacognition (Suhandono, 2017). High school students with FI and FD cognitive styles have conducted metacognition activities in planning, monitoring and evaluating their thought processes and outcomes at each stage of 
solving a geometry problem. Suhandono's research contradicts Kafiar, Kho and Triwiyono (2015) which stated that FI students could solve problems better than FD students. Referring to Anggo (2011) regarding the role of metacognition in problem-solving, we assumed that FI students have better metacognition than FD students in solving problems.

Analytical geometry is a mathematical subject that deals with symbols and algebraic methods used to represent and solve problems in geometry (Bix \& D'Souza, 2016). The essence of analytical geometry is to establish the connection between geometric curves and algebraic equations. This connection makes it possible to reformulate problems in geometry as similar problems in algebra and vice versa. Therefore, good analysis is needed to solve analytic geometry problems. If the problems are word problems, then students highly possibly use Polya's (1973) stages of problem-solving. Every student is possible to have different ways of solving these types of analytic geometry problems. Firstly, students directly work on the problem by using algebraic methods without having to draw geometric objects. Secondly, students need to draw geometric objects which represent the problem, then use the algebraic method. Possible solutions to these problems can be observed using Polya's steps. To solve the problem of analytic geometry well, students must use their metacognitive abilities in each Polya's step. With the possibility of different ways to solve the problem of analytic geometry, it is also possible that there will be similarities or differences in the process of metacognition at each Polya's step for each student, including students who have different cognitive styles (FI and FD).

Anderson (2002) lists the components of metacognition: (1) preparing and planning to learn, (2) choosing and using learning strategies, (3) monitoring the use of strategies, (4) making varied strategies, and (5) evaluating the use of strategies. In solving analytical geometry problems, students can apply the components of metacognition. In the preparation and planning stages, students need to read the questions carefully so they can understand the problem of analytic geometry. After that, students need to identify what is known and what is asked. At the stage of choosing and using a strategy, students need to determine the strategy by connecting the elements that are known to the relevant formulas or concepts and systematically applying these strategies. At this stage, students are allowed to draw elements known in the question in full and vice versa. At the stage of monitoring the use of strategies, students need to be aware of strategies that are less effective, realize the mistakes that arise and try to correct them. At the stage of making various strategies, students need to make alternative strategies to check the results of using the initial strategy. At the stage of evaluating the use of strategy, students compare the initial strategy with alternative strategies to check the correctness of the results obtained and compare which strategies are more effective.

Ismail (2018) showed that male students have a profile of critical thinking: In understanding the problem, students do categorization and clarification of meaning. In devising a plan, they examine their ideas, analyze their arguments and evaluate their arguments. In the implementation step, the skills that arise are drawing conclusions and providing alternative solutions to problems. In the re-checking step, he made self-corrections and self-examination. Suhandono (2017) examined FI and FD students' metacognition in solving problems through the Polya problemsolving steps. He observed how students understand the problem through reading and delivering what is known and being asked, how students determine the problem-solving path, the suitability of implementation and problem-solving planning and in re-checking step he gave re-examination to the students to improve an error found. This study differs from Suhandono (2017) regarding the elements of student metacognition involved in each step of problem-solving and specific to analytic geometry. 
Male students with FI and FD may have similarities and differences in the metacognition profile. After knowing the description of FI and FD students' metacognitive profile, it is expected to provide useful information for lecturers and students, i.e., the lecturers can integrate the process of metacognition by paying attention to the students' different cognitive styles, and male students can correct existing deficiencies from the process of metacognition. In this case, they can solve the problem of analytic geometry correctly. By knowing the shortcomings that exist in the metacognition process, the students are expected to try improving them.

The main problems explored in this study are: (1) students still have difficulties in solving the problem of analytic geometry (Imswatama \& Muhassanah, 2016; Subita \& Kholid, 2017), (2) Male students with FI and FD cognitive styles do not have a different processes of metacognition (Suhandono, 2017), but Kafiar, Kho and Triwiyono (2015) stated that FI students could solve problems better than FD students, (3) FI female students have a better thinking process than FI male students in solving problems (Aini, 2017), and (4) the roles of metacognition in mathematics problem-solving (Anggo, 2011) and the importance of knowing the similarity or difference of students' metacognition which refer to cognitive styles. Based on the description of the problems, it is necessary to conduct research which reveals the metacognition profile of students in solving the problem of analytic geometry reviewed from FI and FD cognitive styles. Thus, this study aimed to describe the metacognition of male students in solving analytical geometry problems referring to cognitive style.

\section{B. Methods}

Participants in this study were two male undergraduate students with FI and FD cognitive styles who enrolled in the course of analytic geometry. Participants were selected based on purposive sampling technique. The subjects were coded as L-FI for male students with FI and L-FD for male students with FD. Male students with FI and FD cognitive styles do not have a different process of metacognition (Suhandono, 2017), but Kafiar, Kho and Triwiyono (2015) stated that FI students could solve problems better than FD students. Meanwhile, metacognition plays a role in problem-solving (Anggo, 2011). This difference is one of the reasons we chose male students as the subject. The other reasons relate to the limitation of the current study such as time and resource.

The data were collected directly by the researchers themselves as the main instrument. The instrument to determine students' cognitive style was a psychiatric test developed by Witkin and Moore (1974), namely the Group Embedded Figures Test (GEFT). Each correct answer was given a value of 1 . The maximum score was 18 points, and the minimum score was 0 point. Gordon and Wyant (1994) stated that someone who has a GEFT test score 12 and above it is classified as FI and someone who has a test score of 11 and below it is classified as FD.

The supporting instrument used in this study was a written test of problem-solving in analytic geometry topic in the form of the essay. Problem-solving tests consisted of two stages: problem-solving test I and problem-solving test II. The reason for choosing these two stages was to obtain valid research data by comparing the results of problem-solving I test on the first data collection and the results of problem-solving test II on the second data collection. Each problemsolving test consisted of 1 question about identical or isomorphic analytic geometry. In this study, data checking was carried out to obtain the level of trust (credibility) of data through time triangulation (Sugiyono, 2012) by comparing the results of the first data collection and the second data collection at different times.

Before the test instrument was used to get research data, the test instrument was validated to three validators. The three validators have stated that problem-solving test instruments problems I and 2 are valid regarding material, construction, and language. Concerning the topic 
on the question it was assessed to have been studied by students, and the answer key had been arranged correctly. Regarding construction, the subject matter is formulated briefly and clearly, and the subject matter is free from statements that can lead to multiple interpretations. In terms of language, the items use communicative language. The following is a problem-solving test I that has been validated.

$A$ circle with center $A(2,3)$ and radius 5 . Points $B(6,6)$ and $C(5,-1)$ are located in the circle. Determine the equation of the $A B C$ triangle altitude line through the center of the circle!

The following is a problem-solving test II that had been validated.

$A$ circle with a center point $A(5,4)$ with a radius of 5 units and a triangle $B C D$ with point coordinates $B(1,1)$ and $D(10,4)$. The $B C$ side is the diameter. Determine the altitude line equation from point $D$ and perpendicular to the side of $B C$ !

Data collection technique in this study used think aloud. The students expressed their byideas using verbal or spoken sentences in the process of solving the problem of analytic geometry so that the data obtained were verbal and written words. The data collected were then analyzed by selecting and identifying data.

The metacognition profile observed in this study refers to the five metacognition components presented by Anderson (2002) which include: (1) preparing and planning learning, (2) choosing and using learning strategies, (3) monitoring the use of strategies, (4) making a variety of strategies, and (5) evaluating the use of strategies. The components of student metacognition can be seen using the four steps to solve the problem from Polya (1973) as follows. At the stage of understanding the problem, the metacognition component observed was preparing to learn to solve problems through reading and understanding problems and mentioning the elements which were known and what was asked in the question. At the stage of devising a plan, the metacognition component observed was planning to learn through activities relating elements contained in the problem with certain concepts or formulas that were relevant to solve the problem and selecting learning strategies through activities determining steps to solve the problem. At the stage of carrying out a plan, the metacognition component observed was using selected strategies to solve the problem and monitoring the use of strategy through the activity of reexamining the results of work by finding errors and correcting errors. At the stage of re-checking, the metacognition component observed was using a variety of strategies to check the correctness of the results obtained from the initial strategy chosen, evaluating the use of strategy through the activity of comparing the initial strategy results and the next strategy used, and checking again and correcting errors found if the strategies used were different.

The process of data analysis in this study was carried out based on the Miles and Huberman (2007) model, namely: (1) data reduction, (2) display and (3) conclusion drawing. In this study, after the data from the first and second collection results were obtained, the data were then grouped based on the stages of the problem-solving process. Furthermore, the data in each step were identified and grouped based on the metacognition components studied. After the data were reduced, the data that has been arranged based on metacognition components according to Anderson were then presented in the form of description and tables. From this presentation, a metacognition profile would be seen well in each research participant based on the FI and FD cognitive style. Conclusions were drawn referring to the data presentation. This conclusion was a description of the metacognition profile of male student with FI and FD cognitive styles in solving the problem. 


\section{Findings and Discussion}

Here are the results of the work of the L-FI participant in answering the problem-solving test 1 and 2.

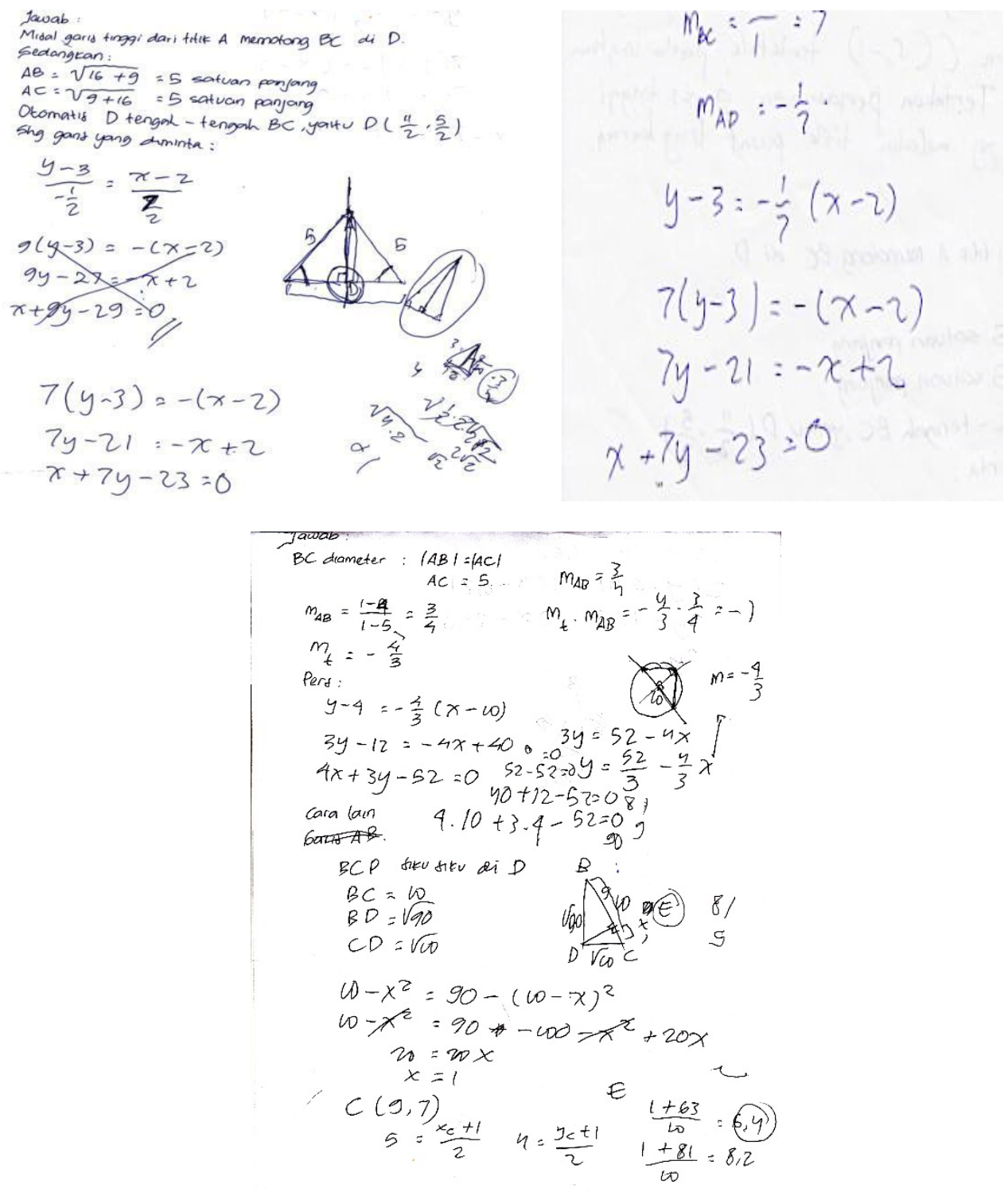

Figure 1. The answers of L-FI participants for problem-solving 1 and 2

The following are the results of interviews with the L-FI participant in working on the problem-solving test I.

L-FI-101 P : What is known and what is asked about the question?

L-FI-102 L-FI : A circle with center $A(2,3)$ and radius 5. Point $B$ and point $C$ are located in a circle. Well, what is asked is the ABC triangle altitude line that goes through the center point.

L-FI-103 P : Do you look for the equation?

L-FI-104 L-FI : Sure. $A$ is a center. $B$ and $C$ are located in the circle, automatically $A B$ and $A C$ are the radius. Automatically $A B=A C$.

L-FI-105 P $\quad$ : You are looking for $A B$ and $A C$ length first. 
L-FI-106 L-FI : I forgot that it was a circle. If it's already known the two sides are the same, automatically the two angles of this triangle are the same. So that we can draw a line which will intersect the BC side in the middle and automatically perpendicular. So that the line that connects $A$ with its intersection is in $B C$, this is for example at point $D$. So that the line through $A D$ is the requested line.

L-FI-107 P : Why are they perpendicular?

L-FI-108 L-FI : It is because the angles are the same. Then we draw the line that intersects the middle and then automatically perpendicular.

L-FI-109 P : Why can it be perpendicular?

L-FI-110 L-FI : I use manual calculations.

L-FI-111 P : you use manual calculations.

L-FI-112 L-FI : Suppose this is 3, 3, 2. It turns out right.

L-FI-113 P : 3, 3, 2?

L-FI-114 L-FI : this is 2, this is 3, this is 3.

L-FI-115 P : Means 2 is divided into 1 and 1?

L-FI-116 L-FI : Yes sir, I use simple strategy.

L-FI-117 P : This means the length of the upright side is the same. That means the Pythagorean theorem applies.

L-FI-118 L-FI : Yes..

L-FI-119 P : What can you conclude?

L-FI-120 L-FI : Two concurrent right triangles.

L-FI-121 P : Then?

L-FI-122 L-FI : Point $D$ is in the middle of $B C$. Even though we have coordinates $B$ and $C$. Point $B$ coordinates (6.6) and point $C$ coordinates (5, -1). So that the coordinates of point $D=(11 / 2 ; 5 / 2)$ are obtained. From the point $D$ and point $A$ it is derived the equation $x-7 y-23=0$.

L-FI-122 states the quotation of the L-FI participant's conversation on problem-solving test 1 on the $22^{\text {nd }}$ interview protocol.

The following are the results of interviews with the L-FI participant when working on the problem-solving test 2 .

L-FI-2-001 P : What is known in the question?

L-FI-2-002 L-FI : Known a circle with a center $(5,4)$ with a radius of 5 units. And the BCD triangle with coordinates $B(1,1)$ and $D(10$, 4). The side $B C$ is the diameter of the circle.

L-FI-2-003 P : What was asked about the question?

L-FI-2-004 L-FI : The altitude line equation through point D.

L-FI-2-005 P : Strategy what you will do to work on the problem?

L-FI-2-006 L-FI : I associate with the line gradient that two perpendicular lines if the gradient is multiplied then the result is -1 .

L-FI-2-007 P : What next?

L-FI-2-008 L-FI : $B C$ is the diameter of the circle. The automatic side of $B C$ also through point A. Automatically the BC line gradient will be equal to $A B$.

L-FI-2-009 P : Why? 
$\begin{array}{lll}\text { L-FI-2-010 } & \text { L-FI } & : \text { Point } C \text { is in the extension of } A B . \\ \text { L-FI-2-011 } & \text { P } & : \text { Don't you need to look for point } C \text { ? } \\ \text { L-FI-2-012 } & \text { L-FI } & : \text { No sir. }\end{array}$

Figure 2 below shows the written answer of the L-FD participant in working on the problemsolving test 1 and 2 .

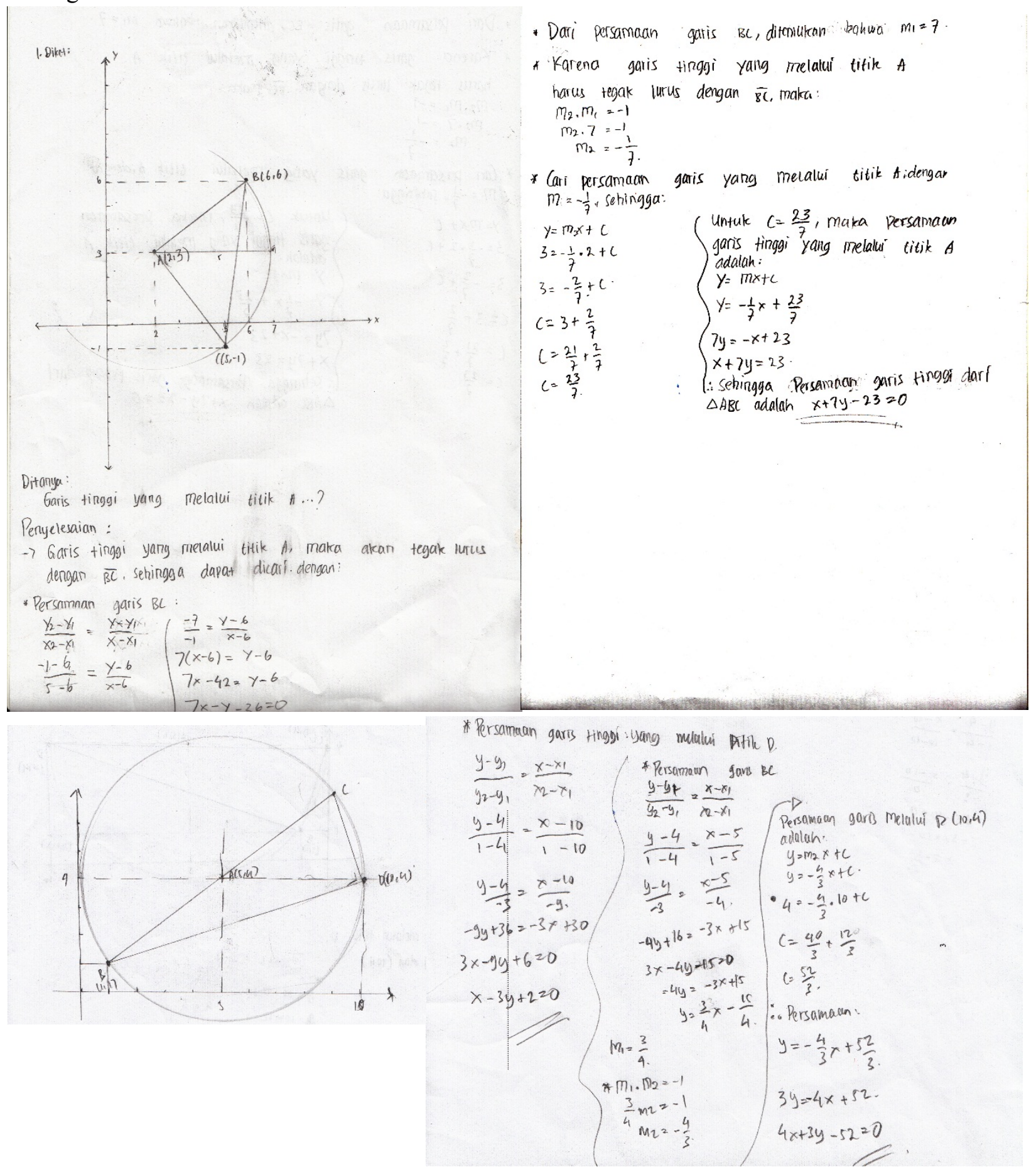

Figure 2. The answers of L-FD participants for problem-solving 1 and 2

The followings are the results of interviews with L-FD participants in working on problemsolving tests I. 


\begin{tabular}{|c|c|c|}
\hline L-FD-101 & $\mathrm{P}$ & What is known and asked about the question? \\
\hline L-FD-102 & L-FD & $\begin{array}{l}\text { A circle with center } A(2,3) \text { and radius } 5 . \text { Points } B \text { and } C \text { are } \\
\text { located in the circle. Asked the equation for the altitude of the } \\
\text { triangle through the center of the circle. }\end{array}$ \\
\hline L-FD-103 & $\mathrm{P}$ & What method do you use? \\
\hline L-FD-104 & L-FD & $\begin{array}{l}\text { The first is that we look for the } B C \text { line equation because what was } \\
\text { asked was the equation of the line through the center point or point } \\
\text { A. Automatically, it intersects the side of } B C \text {. We look for } B C \\
\text { equations which are through points }(6,6) \text { and }(5,-1) \text {. So that the } \\
\text { equation of the BC line is found to be } y=7 x-36 \text {. Then the question } \\
\text { of the high line equation is asked, so it must cut the BC line right. } \\
\text { Well then so we use the theory of } m 1 \text { times } m 2=-1 \text {. m } 1 \text { has been } \\
\text { found } 7 \text {, so the } m 2 \text { is }-1 / 7 \text {. Then we use line theory which only goes } \\
\text { through one point, namely } y=m x+c \text {. Well, the } m 2 \text { is already } \\
\text { known }-1 / 7 \text { earlier. Now we will look for value } c \text {. Because it is } \\
\text { through point A }(2,3) \text {, we enter the value }(2,3) \text { into the equation } y \\
=-1 / 7 x+c \text {. After that we calculate, and we enter and find the } c \\
\text { value equal to } 23 / 7 \text {. So if we enter, we find the equation is } y=-1 / \\
7 x+23 \text {. Or we can make the equation become } 7 y=-x+23\end{array}$ \\
\hline
\end{tabular}

L-FD-105 P : Is c replaced 23/7?

L-FD-106 L-FD : Yes sir.

L-FD-107 P : Is that true?

L-FD-108 L-FD : I am not sure of the value of $C$.

L-FD-109 P : Why?

L-FD-110 L-FD : I rarely determine C value first when I was in middle school.

L-FD-111 P : Is there something wrong?

L-FD-112 L-FD : No sir. I am not sure of the value of $C$

L-FD-113 P : Is there any other way?

L-FD-114 L-FD : For other ways, there may be, but using an actual scale image. Because we humans are not machines, the possibility of truth is slight.

L-FD-115 P : Can you use that method?

L-FD-116 L-FD : Yes, I use image...

L-FD-116 states the quotation of the L-FD participant's conversation on problem-solving test 1 on the 16th interview protocol.

The following are the results of interviews with the L-FD participant in working on the problem-solving test 2 .

\begin{tabular}{|c|c|c|}
\hline L-FD-2-001 & $\mathrm{P}$ & What is known in the question? \\
\hline L-FD-2-002 & L-FD & $\begin{array}{l}\text { Known circle with center }(5,4) \text { and radius } 5 . B C D \\
\text { with known coordinates of point } B \text { and } D . B C \text { is the } \\
\text { diameter. What is asked is the high line equation that } \\
\text { passes point } D \text { and cuts } B C \text {. }\end{array}$ \\
\hline L-FD-2-003 & $\mathrm{P}$ & What strategies do you use to solve the problem? \\
\hline
\end{tabular}




\begin{tabular}{|c|c|c|c|}
\hline L-FD-2-004 & L-FD & : & $\begin{array}{l}\text { I am looking for a high line that intersects the line } \\
\text { before the } D \text { angle. The first is I look for the BC line } \\
\text { equations namely } B(1,1) \text { and } A(5,4) \text {. I use the } \\
\text { method }(y-y 1) /(y 2-y 1)=(x-x I) /(x 2-x 1) \text {. It is } \\
\text { produced } y=3 / 4-15 / 4 \text {. So from this equation, I find } \\
m 1=3 / 4 \text {. Because what is being asked is the } \\
\text { equation of the line that intersects the right side of } \\
B C \text {, I use the property } m 1 \text { times } m 2=-1 \text {. I input } m 1 \\
3 / 4 \text { and found } m 2=-4 / 3 \text {. }\end{array}$ \\
\hline L-FD-2-005 & $\mathrm{P}$ & : & What next? \\
\hline L-FD-2-006 & L-FD & : & $\begin{array}{l}\text { I specify the new line equation using } m 2 \text {, i.e. } y=m 2 \\
x+c . Y=-4 / 3 x+c . \text { Because through point } D(10,4) \\
\text { I change the value of } y \text { with the number } 4 \text { and } x \\
\text { replaced by number } 10 \text { to find the value } c \text {. After } \\
\text { substitution, } c=52 / 3 \text { is obtained. So the equation is } y \\
=-4 / 3 x+52 / 3 . \text { We simplify the two segments by } \\
\text { multiplying } 3, \text { I get } 3 y=-4 x+52 . \text { I change it to its } \\
\text { general form, } 4 x-3 y-52=0\end{array}$ \\
\hline L-FD-2-007 & $\mathrm{P}$ & : & Are you sure? \\
\hline L-FD-2-008 & L-FD & : & Yes. \\
\hline L-FD-2-009 & $\mathrm{P}$ & : & What makes you sure? \\
\hline L-FD-2-010 & L-FD & : & $\begin{array}{l}\text { By understanding the theory that I have learned in } \\
\text { junior high school, that each intersecting line must be } \\
m 1 \text { multiplied by } m 2 \text {, definitely }-1 \text {. }\end{array}$ \\
\hline L-FD-2-011 & $\mathrm{P}$ & : & How to find point $C$ \\
\hline L-FD-2-012 & L-FD & : & $\begin{array}{l}\text { I am looking for point } C \text { automatically to use a } \\
\text { significant scale }\end{array}$ \\
\hline L-FD-2-013 & $\mathrm{P}$ & : & Can you use the usual method? \\
\hline L-FD-2-014 & L-FD & : & Can't use that yet. \\
\hline
\end{tabular}

Based on the results of the analysis of the work of L-FI and L-FD participants, the results of interviews with L-FI and L-FD participants, as well as field notes, it can be obtained a comparison description of the metacognition profile of L-FI participants with L-FD shown on Table 1.

Table 1. The comparative description of the metacognition profile of L-FI participants with LFD

\begin{tabular}{|c|c|c|c|}
\hline No. & Polya's Step & $\begin{array}{c}\text { Metacognition Profile of L-FI } \\
\text { Participant }\end{array}$ & $\begin{array}{c}\text { Metacognition Profile of L-FD } \\
\text { Participant }\end{array}$ \\
\hline 1 & $\begin{array}{l}\text { Understanding } \\
\text { the problem) }\end{array}$ & $\begin{array}{l}\text { a. The L-FI participant reads the } \\
\text { question silently (not read } \\
\text { verbally). } \\
\text { b. The L-FI participant do not } \\
\text { write down the elements that } \\
\text { are known and asked about the } \\
\text { problem but mentions them } \\
\text { orally by looking back at the } \\
\text { question }\end{array}$ & $\begin{array}{l}\text { a. The L-FD participant reads the } \\
\text { question silently (not read } \\
\text { verbally). } \\
\text { b. The L-FD participant does not } \\
\text { write down the elements that are } \\
\text { known and asked about the } \\
\text { problem but mentions them } \\
\text { orally by looking back at the } \\
\text { question. }\end{array}$ \\
\hline 2 & $\begin{array}{l}\text { Devising a } \\
\text { plan }\end{array}$ & $\begin{array}{l}\text { a. The TL-FI participant does } \\
\text { not interpret the known } \\
\text { elements into the image in }\end{array}$ & $\begin{array}{l}\text { a. The L-FD participant interprets } \\
\text { known elements into the image } \\
\text { in cartesian coordinates, then }\end{array}$ \\
\hline
\end{tabular}




\begin{tabular}{|c|c|c|c|}
\hline No. & Polya's Step & $\begin{array}{c}\text { Metacognition Profile of L-FI } \\
\text { Participant }\end{array}$ & $\begin{array}{c}\text { Metacognition Profile of L-FD } \\
\text { Participant }\end{array}$ \\
\hline & & $\begin{array}{l}\text { Cartesian coordinates, but } \\
\text { only draws a small portion of } \\
\text { the components needed to } \\
\text { solve the problem. Then the } \\
\text { participant of L-FI relates the } \\
\text { elements that are obtained by } \\
\text { concepts and formulas related } \\
\text { to problem-solving. } \\
\text { b. The L-FI-A participant } \\
\text { determines a strategy for } \\
\text { solving problems after } \\
\text { identifying the elements that } \\
\text { are known and relating them } \\
\text { to concepts and formulas } \\
\text { related to problem-solving. } \\
\text { The strategy he chose was not } \\
\text { written directly but was } \\
\text { immediately implemented in } \\
\text { systematic steps to get the } \\
\text { intended results. }\end{array}$ & $\begin{array}{l}\text { connects concepts and formulas } \\
\text { related to problem-solving. } \\
\text { b. The L-FD participant } \\
\text { determines a strategy for } \\
\text { solving problems after } \\
\text { interpreting known elements } \\
\text { into the image in cartesian } \\
\text { coordinates and connecting } \\
\text { concepts and formulas related to } \\
\text { problem-solving. The strategy } \\
\text { he chose was not written } \\
\text { directly but was immediately } \\
\text { implemented in systematic steps } \\
\text { to get the intended results. }\end{array}$ \\
\hline 3 & $\begin{array}{l}\text { Carrying out } \\
\text { the plan }\end{array}$ & $\begin{array}{l}\text { a. The L-FI participant } \\
\text { implements strategies chosen } \\
\text { in systematic steps to obtain } \\
\text { the intended results. } \\
\text { b. The L-FI participant monitors } \\
\text { the implementation of its } \\
\text { strategy in solving problems } \\
\text { by realizing that there are } \\
\text { strategies that are less } \\
\text { effective or unnecessary and } \\
\text { check the truth of the } \\
\text { allegations that arise in the } \\
\text { problem-solving process. }\end{array}$ & $\begin{array}{l}\text { a. The L-FD participant } \\
\text { implements strategies chosen in } \\
\text { systematic steps to obtain the } \\
\text { intended results. } \\
\text { b. The L-FD participant monitors } \\
\text { the implementation of its } \\
\text { strategy in solving problems by } \\
\text { looking back at the answers and } \\
\text { not realizing that there are } \\
\text { strategies that are less effective } \\
\text { or do not need to be done. }\end{array}$ \\
\hline 4 & Looking back & $\begin{array}{l}\text { a. The L-FI participant uses a } \\
\text { variety of strategies to solve } \\
\text { problems. } \\
\text { b. The L-FI participant uses a } \\
\text { different strategy and } \\
\text { compares whether the results } \\
\text { obtained are the same or not. } \\
\text { Also, at this stage, the L-FI } \\
\text { participant also checks } \\
\text { whether the results obtained to } \\
\text { meet the criteria used to solve } \\
\text { the problem. }\end{array}$ & $\begin{array}{l}\text { a. The L-FD participant uses a } \\
\text { variety of strategies to solve } \\
\text { problems with many questions. } \\
\text { b. The L-FD participant uses a } \\
\text { variety of strategies, although } \\
\text { with a number of questions and } \\
\text { compares whether the results } \\
\text { have been equal or not. }\end{array}$ \\
\hline
\end{tabular}

The findings of this study (Table 1) reveal that male student uses metacognition in the problem-solving stage. The male student uses their metacognition at the stage of understanding the problem, devising a plan, carrying out the plan, and looking back. This result is relevant to the result of Chusna's (2015) research which states that the male students' thinking processes are as follows. At the stage of understanding the problem, the participant reads the question silently, 
and then the participant mentions the problem in his language; the participant mentions a statement that will be proven. In the stage of devising a plan, based on the knowledge possessed, the participant determines the adequacy of data with one method of verification. At the stage of carrying out the plan, the participant uses the concepts needed to prove. At the stage of looking back, there is a participant who checks the answers by checking the evidence that has been written and by taking a sample number.

This study found that there are similarities in the metacognition profile between the male student who has FI cognitive style and the male student who has an FD cognitive style. FI male students and FD male students read questions silently and do not write down the elements that are known and what are asked, but mention them verbally. It is because, at the stage of understanding the problem, the male student reads the questions silently then mentions problems with his language (Chusna, 2015). There are also differences in the profile of metacognition of male student who has FI cognitive style with a male student who has FD cognitive style at the stage of devising a plan, carrying out the plan, and looking back.

At the stage of devising the plan, there are differences in metacognition profiles, that is, a male student with FI cognitive style does not draw the elements that are known in full, only a small part is considered necessary. This can be seen in Figure 1. Whereas for a male student with FD cognitive style draws elements that are known in full. This can be seen in Figure 2. It is because FD individuals require more explicit instruction than FI individuals (Witkin \& Moore, 1974).

At the stage of carrying out the plan of a male student with FI cognitive style monitors the implementation of its strategy in solving problems by realizing that there are strategies that are less effective or unnecessary to do and checks the truth of the allegations that arise in the problem-solving process. FI male student realizes that in problem-solving test questions he does not need to calculate the length of $\mathrm{AB}$ and $\mathrm{AC}$, because $\mathrm{B}$ and $\mathrm{C}$ are in a circle, so $\mathrm{ABC}$ triangle is isosceles. Meanwhile, a male student with the FD cognitive style monitors the implementation of its strategy in solving problems by looking back at the answers and does not realize that there are strategies that are less effective or do not need to be done. In solving problem 2, FD male students find out BD line equations which are not required in determining the high line equations that are asked. It is because FI individuals have a better focus than FD individual on the chosen strategy (Witkin \& Moore, 1974).

At the stage of looking back, a male student with FI cognitive style uses a varied strategy and checks whether the results obtained to meet the criteria used to solve the problem. In answering the problem 1 FI male student uses the initial strategy by looking for equations that go through two points. Whereas in other strategies, FI male student uses a method of finding line equations that are known by one point and its gradient. On problem-solving 2, after finding the altitude line equation that is asked, the FI male student tests whether point $\mathrm{D}$ is included in the line and whether the line is perpendicular to the side of the base. Whereas, a male student with FD cognitive style uses a variety of strategies to solve the problem although with some questions. It is because FI individuals are better able to provide problem-solving strategies by utilizing information obtained and less dependent on strategies that are already available (Witkin \& Moore, 1974).

The difference in the metacognition profile between FI male student and FI male student in this study is also due to the cognitive style that has a significant effect on students' mathematical problem-solving abilities (Murtafiah \& Amin, 2018). It means that FI students have better problem-solving skills than FD students. Students with FI cognitive style are more analytical so they can understand verbal statements from problems and change them into mathematical sentences, determine the right formula in problem-solving and express knowledge and steps that are appropriate to solve problems; students can complete each planned step and get the correct answer; in the final step, students check the answers (Murtafiah, 2017). Meanwhile, students 
with FD cognitive style are less able to change the verbal language into mathematical sentences (Murtafiah, 2017).

Students who have a FI cognitive style have a higher level of ability at SOLO's taxonomy level regarding solving mathematical problems than students who have a cognitive style of FD (Ahmar, Rahman, \& Mulbar, 2017). However, when the information is already available in his mind, FI students do not need an analytical approach to solve the problems. So that FI students have better performance than FD students in problem-solving.

The findings in this study contribute to the understanding that FI and FD male students' have a different and similar metacognitive profile when solving mathematical problems. It implies that for mathematics educators, the strategy of presenting problem-solving activity in mathematics teaching should consider the similarity and the difference of students' metacognition profile. We consider two subjects as the limitation in this study. Thus, further research needs to include female students as the subjects so that their metacognitive profile can be compared to male students by reviewing cognitive styles.

\section{Conclusion}

In solving mathematical problems which refer to Polya (1973), FI and FD male student have the same metacognition profile at the stage of understanding the problem, but they have a different way in planning, doing the plan and re-checking the result of problem-solving. The findings imply that FI and FD male students need to apply the process of metacognition in order to solve the problem of analytic geometry well, i.e., read the questions carefully in order to understand the problem, identify what is known and what is asked, determine strategies by relating known elements with relevant formulas or concepts and applying these strategies systematically, aware of strategies that are less effective, realize the mistakes that arise and try to fix them, create alternative strategies to check the results of using the initial strategy, compare the initial strategy with alternative strategies to check the truth of the results obtained, and examine which two strategies are more effective.

\section{Acknowledgment}

The researcher expressed his gratitude to the Directorate of Research and Community Service, Directorate General of Research and Development Strengthening of the Ministry of Research, Technology, and Higher Education which has funded the implementation of this research.

\section{References}

Ahmar, A. S., Rahman, A., \& Mulbar, U. (2017). Analisis kemampuan pemecahan masalah matematika mahasiswa statistika FMIPA UNM angkatan 2015 berdasarkan taksonomi SOLO dan ditinjau dari gaya kognitif. Retrieved from eprints.unm.ac.id/3612/1/Artikel Ansari-Rahman-Usman-eprints.pdf

Aini, K. N. (2017). Proses berpikir mahasiswa laki-laki dan perempuan dengan gaya kognitif field independent dalam memecahkan masalah. INSPIRAMATIKA, 3(1), 16-23

Anderson, N. J. (2002). The role of metacognition in second language teaching and learning. ERIC Digest. ERIC Clearinghouse on Languages and Linguistics, 4646 40th Street N.

Anggo, M. (2011). Pelibatan metakognisi dalam pemecahan masalah matematika. Edumatica, 01(01), 25-32. Doi:10.1109/MACE.2011.5988797

Bix, R. A., \& D'Souza, H. J. (2016). Analytic geometry. Retrieved from https://www.britannica.com/science/analytic-geometry

Chairani, Z. (2016). Metakognisi siswa dalam pemecahan masalah matematika. Yogyakarta: Deepublish.

Chusna, D. S. A. (2015). Proses berpikir mahasiswa dalam memecahkan masalah pembuktian ditinjau dari perbedaan gender (Penelitian Dilakukan terhadap Mahasiswa Prodi Pendidikan Matematika 
JPMIPA FKIP UNS Angkatan 2013 Tahun Ajaran 2013/2014) (other). Universitas Sebelas Maret.

Gordon, H. R. D., \& Wyant, L. J. (1994). Cognitive style of selected international and domestic graduate students at Marshall University. Retrieved from https://files.eric.ed.gov/fulltext/ED372711.pdf

Hudojo, H. (2003). Pengembangan kurikulum dan pembelajaran matematika. Malang: Jurusan Matematika Universitas Negeri Malang.

Imswatama, A., \& Muhassanah, N. (2016). Analisis kesalahan mahasiswa dalam menyelesaikan soal geometri analitik bidang materi garis dan lingkaran. Suska Journal of Mathematics Education, 2(1), 1-12. Doi: $10.24014 /$ sjme.v2i1.1368

Ismail. (2018). Critical thinking skills of an eighth grade male student with high mathematical ability in solving problem. Journal of Physics: Conference Series, 947, 012073. Doi: 10.1088/17426596/947/1/012073

Kafiar, E., Kho, R., \& Triwiyono, T. (2015). Proses berpikir siswa SMA dalam memecahkan masalah matematika pada materi SPLTV ditinjau dari gaya kognitif field independent dan field dependent. Jurnal Ilmiah Matematika dan Pembelajarannya, 2(1), 39-51.

Mammarella, N., Borella, E., \& Fairfield, B. (2014). Applying the concept of cognitive style to cognitive aging. Ann Gerontol Geriatric Res, 1(2), 1-3. Retrieved from https://pdfs.semanticscholar.org/8ecd/b30e15aadfb165a28285835c34580d3df360.pdf

Miles, M. B., \& Huberman, A. M. (2007). Analisis data kualitatif buku sumber tentang metode-metode baru. Jakarta: Universitas Indonesia.

Munandar, H. (2010). Hubungan kesadaran metakognitif dan gaya kognitif dengan kemampuan metakognitif peserta didik kelas XI IPA SMA Negeri se-kota Parepare. Prosiding Seminar Nasional, $02(1), 128-136$.

Murtafiah, M. (2017). Deskripsi kemampuan pemecahan masalah matematika ditinjau dari gaya kognitif mahasiswa pendidikan matematika Universitas Sulawesi Barat. Jurnal Pendidikan MIPA, 7(1), 48-52.

Murtafiah, M., \& Amin, N. (2018). Pengaruh gaya kognitif dan gender terhadap kemampuan pemecahan masalah matematika. Jurnal Penelitian dan Pembelajaran Matematika, 11(1), 75-82. Doi:10.30870/jppm.v11i1.2986

Ngilawajan, D. A. (2013). Proses berpikir siswa SMA dalam memecahkan masalah matematika materi turunan ditinjau dari gaya kognitif field independent dan field dependent. Pedagogia: Jurnal Pendidikan, 2(1), 71-83. Doi:10.21070/pedagogia.v2i1.48

Papleontiou-louca, E. (2003). The concept and instruction of metacognition. Teacher Development, 7(1), 9-30

Polya, G. (1973). How to solve it. Princeton (New Jersey): Princeton University Press.

Subita, R. K., \& Kholid, M. N. (2017). Analisis kesulitan belajar mata kuliah geometri analitik bidang pada mahasiswa program studi pendidikan matematika UMS tahun akademik 2016/2017. Surakarta. Retrieved from eprints.ums.ac.id/53023/

Sugiyono. (2012). Metode Metode penelitian kuantitatif, kualitatif, dan R\&D. Bandung: Alfabeta.

Suhandono, Y. (2017). Proses metakognitif dalam pengajuan masalah geometri berdasarkan gaya kognitif field dependent dan field independent. Jurnal Review Pembelajaran Matematika, 2(1), 40. Doi:10.15642/jrpm.2017.2.1.40-59

Udiyono, U., \& Yuwono, M. R. (2018). The correlation between cognitive style and students' learning achievement on geometry subject. Infinity Journal, 7(1), 35-44. Doi:10.22460/infinity.v7i1.p35-44

Ulya, H. (2015). Hubungan gaya kognitif dengan kemampuan pemecahan masalah matematika siswa. Jurnal Konseling GUSJIGANG, 1(2). Doi:10.24176/jkg.v1i2.410

Witkin, H. A., \& Moore, C. (1974). Cognitive style, and the teaching learning process. Paper Presented at the Annual Meeting of the American Educational Research Association (59th, Chicago, Illinois, April 1974). 